\title{
Identification of Genes Involved in Smooth Muscle Cell Protein Synthesis with Increased Expression in Atheromatous Plaques Associated with Neointimal Hyperplasia after Bare-Metal Stenting: A GENESIS-R Study
}

\author{
Alexandre C. Zago ${ }^{1}$, Marco A. Costa ${ }^{2}$, Alcides J. Zago ${ }^{3}$, Juliane S. Rossato ${ }^{4}$, Bruno S. Matte ${ }^{5}$, \\ German Iturry-Yamamoto ${ }^{6}$, Márcio Mossmann ${ }^{7}$, Ricardo Savaris ${ }^{8}$, Mariano Albertal ${ }^{9}$, Cristiane S. Rocha $^{10}$, \\ Aileen M. Healy ${ }^{11}$, Russell Walker ${ }^{12}$, Satoko Tahara ${ }^{13}$, Daniel I. Simon ${ }^{14}$
}

\begin{abstract}
Background: Coronary restenosis is a poorly understood phenomenon that remains a challenge even in the drug-eluting stent era. This study aimed to identify genes involved in the synthesis of structural and functional proteins in smooth muscle cells with increased expression in human atheromatous plaques associated with neointimal hyperplasia after bare-metal stent implantation. Methods: Atheromatous plaques were obtained by directional atherectomy prior to stenting. A gene expression analysis was performed using the Affymetrix GeneChip system. The patients were subjected to intravascular ultrasound six months after the procedure for an in-stent volumetric analysis. The correlation between gene expression in atheromatous plaques and the percentage of in-stent intimal hyperplasia was evaluated. Results: Most patients were male $(85.7 \%)$ with a mean age of $60.2 \pm 11.4$ years; $35.7 \%$ were diabetic, and the percentage of in-stent intimal hyperplasia was $29.9 \pm 18.7 \%$. There was no change in the percentage of in-stent intimal hyperplasia in patients with or without diabetes $(29.5 \%$ vs. $30.7 \%$; $\mathrm{P}=0.89)$. There was no correlation between the stent length and the percentage of in-stent intimal hyperplasia $(r=-0.26 ; P=0.26)$, or between the stent diameter and the percentage of in-stent intimal hyperplasia $(r=0.14 ; P=0.56)$. Eight genes related to smooth muscle cell structural and functional protein synthesis had a positive
\end{abstract}

\section{RESUMO}

Identificação de Genes Envolvidos na Síntese
de Proteínas de Células Musculares Lisas com
Expressão Aumentada em Placas Ateromatosas
Associados a Hiperplasia Neointimal após Implante
de Stents Não Farmacológicos: Estudo GENESIS-R
Introdução: A reestenose coronária é um fenômeno pouco com-
preendido e que permanece como um desafio mesmo na era dos
stents farmacológicos. Este estudo tem como objetivo identificar
genes envolvidos na síntese de proteínas estruturais e funcionais
de células musculares lisas com expressão aumentada em placas
ateromatosas de humanos associados a hiperplasia neointimal
após o implante de stents não farmacológicos. Métodos: Placas
ateromatosas foram obtidas mediante aterectomia direcionada,
previamente ao implante do stent. A análise da expressão dos
genes foi realizada utilizando-se o sistema Affymetrix GeneChip.
Os pacientes foram submetidos a ultrassom intracoronário
6 meses após o procedimento para análise volumétrica intrastent.
Foi avaliada a correlação entre a expressão gênica de placas
ateromatosas e o porcentual de hiperplasia intimal intrastent.
Resultados: A maioria dos pacientes era do sexo masculino
$(85,7 \%)$, com $60,2 \pm 11,4$ anos de idade, $35,7 \%$ eram diabé-
ticos e o porcentual de hiperplasia intimal intrastent foi de
$29,9 \pm 18,7 \%$. Não houve variação do porcentual de hiperpla-
sia intimal intrastent entre os pacientes com ou sem diabetes

$1 \mathrm{PhD}$ in Cardiology. Professor of the Post-Graduation Program in Cardiology of Universidade Federal do Rio Grande do Sul. Interventionist cardiologist at the Hospital de Clínicas de Porto Alegre. Porto Alegre, RS, Brazil.

2 PhD in Cardiology. Head of the Hemodynamics Unit of the UH Hospitals of the Case Western University. Cleveland, USA.

${ }^{3} \mathrm{PhD}$ in Cardiology. Full Professor at the Faculdade de Medicina of the Universidade Federal do Rio Grande do Sul. Porto Alegre, RS, Brazil.

${ }^{4}$ Master's degree in Science. Biologist at the Hospital de Clínicas de Porto Alegre. Porto Alegre, RS, Brazil.

${ }^{5}$ Master's degree student in Cardiology. Interventionist cardiologist at the Hospital de Clínicas de Porto Alegre. Porto Alegre, RS, Brazil.

${ }^{6} \mathrm{PhD}$ in Cardiology. Cardiologist at the Hospital de Clínicas de Porto Alegre. Porto Alegre, RS, Brazil.

${ }^{7}$ Resident physician in Cardiology at the Hospital de Clínicas de Porto Alegre. Porto Alegre, RS, Brazil.

\footnotetext{
${ }^{8} \mathrm{PhD}$ in Gynecology. Specialist in Statistics at the Hospital de Clínicas de Porto Alegre. Porto Alegre, RS, Brazil.

${ }^{9} \mathrm{PhD}$ in Cardiology. Interventionist cardiologist at the Instituto Cardiovascular de Buenos Aires. Buenos Aires, Argentina.

${ }^{10} \mathrm{PhD}$ in Statistics. Statistician at the Universidade Estadual de Campinas. Campinas, SP, Brazil.

${ }^{1} \mathrm{PhD}$ in Science. Biologist at Millennium Pharmaceuticals. Cambridge, USA.

${ }^{12}$ Biologist at Millennium Pharmaceuticals. Cambridge, USA.

${ }^{13}$ Cardiologist and interventionist cardiologist at UH Hospitals of the Case Western University. Cleveland, USA.

${ }^{14}$ Cardiologist and interventionist cardiologist. Head of the Cardiology Service at the UH Hospitals of the Case Western University. Cleveland, USA Correspondence to: Alexandre do Canto Zago. Rua Ramiro Barcelos, 2.650 - $2^{\circ}$ andar - Porto Alegre, RS, Brazil - CEP 90035-903

E-mail: zagoac@uol.com.br
}

Received on: 3/26/2012 • Accepted on: 5/30/2012 
correlation with the percentage of in-stent intimal hyperplasia. Conclusions: De novo coronary lesions exhibited an increased expression of genes related to the synthesis of structural and functional proteins in smooth muscle cells and were associated with future significant in-stent neointimal hyperplasia, thus emerging as novel therapeutic targets.

DESCRIPTORS: Stents. Drug-eluting stents. Coronary restenosis. Gene expression. Atherectomy. Coronary.

$\mathbf{N}$ eointimal proliferation is the main physiopathological mechanism of intrastent restenosis that, even after the introduction of drug-eluting stents, still remains a problem. Neointimal proliferation is responsible for most adverse cardiovascular events in patients undergoing percutaneous coronary intervention. ${ }^{1-3}$ It is a cicatricial process resulting from the trauma caused by the stent implantation on the vessel wall. The vessel wall smooth muscle cells that are involved in restenosis migrate from the tunica media to the intimal layer of the coronary artery, proliferate, and cause the abundant production of the extracellular matrix..$^{-4}$ Several studies with coronary angiography and intracoronary ultrasound have demonstrated that the atheromatous plaque has basal characteristics predictive of restenosis. ${ }^{5-7}$ However, studies designed to identify genetic predictors of restenosis evaluated only neointimal tissue. ${ }^{8,9}$ Thus, the currently available genetic data on atheromatous plaques in humans are limited and virtually insignificant when its association with restenosis is assessed.

The aim of this study was to evaluate the association between the expression of genes involved in the synthesis of smooth muscle cell structural and functional proteins in atheromatous plaques (de novo lesion) in humans and neointimal proliferation after bare-metal stent implantation.

\section{METHODS}

\section{Sample}

Overall, 40 patients with coronary artery disease and an indication of percutaneous coronary intervention underwent guided atherectomy followed by bare-metal stenting. The exclusion criteria were saphenous vein bypass lesion, ostial lesion of the right coronary artery, intrastent restenosis, and history of heart transplantation or dilated or restrictive cardiomyopathy. The study was approved by the Ethics and Research Committee of the
(29,5\% vs. 30,7\%; P = 0,89). Não houve correlação entre a extensão do stent e o porcentual de hiperplasia intimal intrastent $(r=-0,26 ; P=0,26)$ ou entre o diâmetro do stent e o porcentual de hiperplasia intimal intrastent $(r=0,14 ; P=0,56)$. Oito genes envolvidos na síntese de proteínas estruturais e funcionais de células musculares lisas apresentaram correlação positiva com o porcentual de hiperplasia intimal intrastent. Conclusões: As lesões coronárias de novo apresentam expressão aumentada de genes relacionados com a síntese de proteínas estruturais e funcionais de células musculares lisas associados a futura hiperplasia neointimal intrastent significativa, surgindo como novos alvos terapêuticos.

DESCRITORES: Stents. Stents farmacológicos. Reestenose coronária. Expressão gênica. Aterectomia coronária.

Hospital de Clínicas de Porto Alegre (Porto Alegre, RS, Brazil), and all patients were included after signing an informed consent.

\section{Procedure}

The patients were submitted to intracoronary ultrasound assessment prior to percutaneous coronary intervention to obtain data related to the atheromatous plaque and vessel size. Subsequently, the atherectomy was performed with the guidance of a Flexicut catheter (Guidant Corp., Temecula, CA, USA) to remove the atheromatous plaque. Guided atherectomy was performed using an 8-F guide catheter; the balloon was inflated under low pressure (approximately $0.5 \mathrm{~atm}$ ), and the device was driven at a speed of 2,000 rpm, aiming to excise the atheromatous plaque. ${ }^{9}$ The procedure was successfully and uneventfully performed in 40 patients, yielding a satisfactory amount of material (atheromatous plaque). Finally, the patients underwent bare-metal stenting followed by an assessment using intracoronary ultrasound to ensure proper stent expansion and apposition. When necessary, post-dilation was performed, followed by a new assessment using intracoronary ultrasound.

\section{Quantitative analyses}

Quantitative coronary analysis and ultrasound assessment were performed after administering bolus intracoronary nitrate during percutaneous coronary intervention and angiographic and ultrasound restudies. The intracoronary ultrasound images were acquired using a motorised traction device at $0.5 \mathrm{~mm} / \mathrm{s}$. A quantitative angiographic analysis was performed by independent researchers at the Hospital de Clínicas de Porto Alegre, whereas ultrasound analyses were performed by independent researchers at the UH Hospitals (Cleveland, OH, USA). Stent restenosis was defined as stenosis with an intrastent diameter $\geq 50 \%$ upon angiographic restudy. The minimum luminal diameter 
and percentage of intrastent stenosis were measured in each stent. Late intrastent luminal loss was calculated as the post-implantation minimum luminal stent diameter minus the minimum luminal diameter upon angiographic restudy. The intimal hyperplasia volume was calculated as the stent volume minus the luminal volume. The percentage of intimal hyperplasia was defined as the intimal hyperplasia volume divided by the stent volume. The percentage of intimal hyperplasia was determined to be correlated with the gene expression parameter, as it is more representative of neointimal proliferation and allows for the equalisation of different diameters and extensions of the analysed stents.

\section{Gene expression analysis}

The fragments of atheromatous plaque (de novo lesion) were placed in Eppendorf tubes containing RNA Stat 60, stored in liquid nitrogen and subsequently sent to the Millennium Pharmaceuticals Laboratory (Cambridge, MA, USA) for gene expression analysis. The ribonucleic acid (RNA) was isolated from atheromatous plaque samples through homogenisation in the PowerGen equipment model 125 (Thermo Fisher Scientific - Waltham, MA, USA), followed by extraction with chloroform, precipitation with isopropanol, washing with $75 \%$ ethanol and, finally, dissolving in ribonuclease-free water. The RNA concentration was measured using a NanoDrop spectrophotometer (Thermo Fisher Scientific), and the quality and purity of the RNA were assessed using a RNA 6000 peak or nano assay (Agilent 2100 Bioanalyzer, Agilent Technologies - Santa Clara, CA, USA). Finally, the RNA sample was amplified using a specific protocol, and the gene expression of each sample was measured using the chips and the Affymetrix GeneChip microarray system (Affymetrix - Santa Clara, CA, USA).

\section{Statistical analysis}

Categorical variables were expressed as absolute numbers and percentages and continuous variables as the mean \pm standard deviation. Student's $t$-test was used to assess the relationship between diabetes mellitus and the percentage of intimal hyperplasia. Pearson's correlation was used to evaluate the relationship between the stent length and diameter and the percentage of intimal hyperplasia, as well as the relationship between gene expression and the amount of neointimal hyperplasia expressed as the percentage of intimal hyperplasia. A total of 29 atheromatous plaques were assessed as required for rho $(r) \geq 0.5$, a statistical power of $80 \%$, and an alpha error $(\mathrm{P})<0.05$. Nineteen atheromatous plaques were required for $r \geq 0.6$, a statistical power of $80 \%$, and $\mathrm{P}<0.05$ (two-tailed). ${ }^{10}$

\section{RESULTS}

Overall, 40 patients underwent guided atherectomy followed by bare-metal stenting, and 28 of them provided atheromatous plaque samples with an RNA amount that was suitable for analysis (one atheromatous plaque/ patient). Clinical and procedural characteristics demonstrated a mean age of $60.2 \pm 11.4$ years and diabetes mellitus in $35.7 \%$ of the analysed patients (Table 1 ). The volume of intimal hyperplasia in the restudy was $52.8 \pm 28.2 \mathrm{~mm}^{3}$, whereas the percentage of intimal hyperplasia was $29.9 \pm 18.7 \%$ (Table 2 ).

There was no significant variation in the percentage of neointimal hyperplasia in the restudy between patients with or without diabetes mellitus $(29.5 \%$ in diabetics and $30.7 \%$ in non-diabetics, $\mathrm{P}=0.89$ ). Moreover, there was no significant correlation between the stent length and the percentage of intimal hyperplasia $(r=-0.26$; $P=0.26)$, or between the stent diameter and the percentage of intimal hyperplasia $(r=0.14 ; P=0.56)$.

A gene expression analysis indicated a positive correlation between eight genes involved in the smooth muscle cell structural and functional protein synthesis and the percentage of intimal hyperplasia (Table 3).

TABLE 1

Clinical and Angiographic Characteristics

\begin{tabular}{lc}
\hline & $\mathbf{n}=\mathbf{2 8}$ \\
\hline Age, years & $60.2 \pm 11.4$ \\
Male gender, $\mathrm{n}(\%)$ & $24(85.7)$ \\
Diabetes mellitus, $\mathrm{n}(\%)$ & $10(35.7)$ \\
Systemic arterial hypertension, $\mathrm{n}(\%)$ & $18(64.3)$ \\
Dyslipidemia, $\mathrm{n}(\%)$ & $17(60.7)$ \\
Smoking, $\mathrm{n}(\%)$ & $15(53.6)$ \\
Acute coronary syndrome, $\mathrm{n}(\%)$ & $22(78.6)$ \\
Coronary arteries, $\mathrm{n}$ (\%) & \\
Left anterior descending & $18(64.3)$ \\
Circumflex & $4(14.3)$ \\
Right coronary & $6(21.4)$ \\
pre-intervention angiographic findings & \\
Reference vessel diameter, mm & $3.49 \pm 0.22$ \\
Lesion length, mm & $16.3 \pm 4.8$ \\
Stenosis, \% & $76.2 \pm 10.1$ \\
Minimal luminal diameter, mm & $0.83 \pm 0.36$ \\
Post-intervention angiographic & \\
findings & \\
Intrastent minimal luminal & \\
diameter, mm & \\
Residual stenosis, mm & \\
Procedure details & \\
Stent length, mm & \\
Stent /coronary diameter ratio & \\
\hline $\mathrm{n}=$ number of patients. & \\
\hline & \\
\hline
\end{tabular}




\section{DISCUSSION}

Restenosis is an important limitation of percutaneous coronary intervention. Although drug-eluting stents have reduced restenosis rates when compared with bare-metal stents, intrastent restenosis still occurs in $7 \%$ to $8 \%$ of patients, particularly in high-risk situations such as long lesions, small-calibre vessels, and patients with diabetes mellitus or chronic renal failure..$^{2,3}$ For this reason, and due to other problems such as intrastent thrombosis and

TABLE 2

Ultrasonographic and Angiographic Restudy

\begin{tabular}{lc}
\hline & $\mathbf{n}=\mathbf{2 8}$ \\
\hline Late loss, $\mathrm{mm}$ & $1.07 \pm 0.75$ \\
Late loss index & $0.43 \pm 0.24$ \\
Stent volume, $\mathrm{mm}^{3}$ & $198 \pm 56.3$ \\
Lumen volume, $\mathrm{mm}^{3}$ & $145.3 \pm 51.8$ \\
Neointimal volume, $\mathrm{mm}^{3}$ & $52.8 \pm 28.2$ \\
Percentage of intimal hyperplasia, $\%$ & $29.9 \pm 18.7$ \\
\hline $\mathrm{n}$ = number of patients. & \\
\hline
\end{tabular}

the need for prolonged dual antiplatelet therapy, there is continued interest in understanding the mechanisms involved in the physiopathology of restenosis.

After the mechanical trauma caused by stent implantation, a series of events occurs that determines the proliferation of smooth muscle cells and abundant extracellular matrix synthesis, which are the main neointimal components. ${ }^{1,10-13}$ The results of this study indicate that the atheromatous plaques treated by baremetal stenting and that develop significant neointimal hyperplasia exhibit an increased expression of genes related to smooth muscle cell structural and functional protein synthesis prior to stent implantation. Consequently, the results of this study suggest that the atheromatous plaque has an inherent predisposition to significant neointimal formation that precedes stent implantation. These data are being described for the first time, as there are no reports of similar studies in the literature.

The identification of the enhanced expression of genes related to smooth muscle cell structural and functional protein synthesis, which constitutes the cellular basis of restenosis, in atheromatous plaques prone to intrastent restenosis opens a new path for the development of cell antiproliferative drugs that can act on the newly formed protein. In the present results, a

TABLE 3

Correlation between Genes Involved in Smooth Muscle Cell Structural and Functional Protein Synthesis and Percentage of Intimal Hyperplasia

\begin{tabular}{|c|c|c|c|}
\hline \multirow[b]{2}{*}{$\mathbf{P}$} & \multirow[b]{2}{*}{ Correlation } & \multicolumn{2}{|l|}{ Gene } \\
\hline & & Description & Function \\
\hline 0.0000 & 0.78 & $\begin{array}{c}\text { CNN1 } \\
\text { (Calponin 1, smooth muscle) }\end{array}$ & Smooth muscle structural protein \\
\hline 0.0012 & 0.67 & $\begin{array}{c}\text { MYH11 isoform } 1 \\
\text { (Myosin heavy chain } 11 \text { isoform, smooth muscle) }\end{array}$ & Smooth muscle structural protein \\
\hline 0.0030 & 0.63 & $\begin{array}{c}\text { MYH11 isoform } 2 \\
\text { (Myosin, heavy chain 11, smooth muscle) }\end{array}$ & Smooth muscle structural protein \\
\hline 0.0046 & 0.61 & $\begin{array}{c}\text { LMOD1 } \\
\text { (Leiomodin 1, smooth muscle) }\end{array}$ & Smooth muscle structural protein \\
\hline 0.0148 & 0.54 & $\begin{array}{c}\text { MYL9 } \\
\text { (Myosin light chain 9, regulatory) }\end{array}$ & Smooth muscle structural protein \\
\hline 0.0152 & 0.53 & $\begin{array}{c}\text { TPM1 } \\
\text { (Tropomyosin alpha-1) }\end{array}$ & Smooth muscle cell contractility \\
\hline 0.0157 & 0.53 & $\begin{array}{c}\text { MYLK } \\
\text { (Myosin light chain kinase) }\end{array}$ & Smooth muscle cell contractility \\
\hline 0.0258 & 0.51 & $\begin{array}{c}\text { SMTN } \\
\text { (Smoothelin) }\end{array}$ & Smooth muscle structural protein \\
\hline 0.0232 & 0.50 & $\begin{array}{c}\text { CALD1 } \\
\text { (Caldesmon 1) }\end{array}$ & Smooth muscle activity regulation \\
\hline
\end{tabular}


microarray analysis has identified two mRNA isoforms of myosin heavy chain 11, which supports the role of an increased production of proteins related to the structural development of smooth muscle cells. Isoforms are mRNAs with distinct nucleotide sequences that are formed by alternative splicing, and are capable of producing the same protein. Each gene produces multiple mRNAs and isoforms. ${ }^{14}$ The identification of mRNA isoforms in specific genes with increased expression emphasises the discovery of non-random findings, and further supports the obtained results.

Cells are capable of following alternative metabolic pathways that allow cell cycle progression, which explains the significant failure rate of drug-eluting stents that deliver commercially available cell antiproliferative drugs to prevent restenosis. Another important aspect to be discussed is the delayed stent endothelialisation, requiring prolonged use of dual antiplatelet therapy due to the risk of stent thrombosis. This therapy is a serious limitation for patients who need to undergo planned surgeries and for high-risk patients who require emergency surgery, in addition to the increased risk of minor and/or major bleeding. ${ }^{15-19}$ Therefore, gene therapy aimed at inhibiting smooth muscle cell structural and functional protein synthesis constitutes a new paradigm for the production of DES that can act by selectively inhibiting smooth muscle cell proliferation without affecting the physiological production of endothelial cells and, consequently, stent endothelialisation in a short-time interval, as it occurs with bare-metal stents.

The influence of clinical factors, such as diabetes mellitus, and of angiographic factors, such as lesion length and vessel size, on the intrastent restenosis of bare-metal stents is well established.,20-23 Clinical studies have demonstrated that diabetes is a strong independent predictor of stent restenosis, and that long lesions and small-calibre vessel lesions are also independent predictors of intrastent restenosis. Therefore, these well-known clinical and angiographic factor predictors of intrastent restenosis were assessed to analyse their influence on the present sample, aiming to identify statistically possible confounding factors. The results indicated no association between diabetes mellitus and the intrastent neointimal hyperplasia volume. Moreover, there was no correlation between the stent length, which is directly associated with lesion extension, and the neointimal hyperplasia volume; there was also no correlation between the stent diameter, which is directly associated with the vessel diameter, and the neointimal hyperplasia volume. The results of this study, therefore, did not suffer from the influence of clinical and angiographic factors, and the analysis of these results is restricted to cell and genetic factors.

The analysis of gene expression using mRNA microarray technology has become a popular tool to simultaneously evaluate the expression of thousands of genes and has been widely applied in cardiovascular research to detect gene expression patterns under different conditions. There are few studies available in the literature that use this technique to assess gene expression in atherosclerotic plaques and neointimal intrastent in humans. In one study, ten neointimal specimens removed by guided atherectomy were compared with seven coronary artery samples and seven gastrointestinal artery samples. ${ }^{9}$ The authors reported different genes with increased expression in the neointima when compared with the aforementioned arteries. In another study, Ashley et al. ${ }^{8}$ compared samples of atheromatous plaques with tissue derived from intrastent restenosis by histological and gene expression analysis. Histology indicated a higher amount of cells and fewer inflammatory infiltrates and lipid pools in the restenosis group compared with the atheromatous plaque group. The gene expression analysis demonstrated a predominance of cell proliferation and the inflammatory/immune response in the restenosis group when compared with the atheromatous plaque group. The network analysis highlighted two modules of gene expression as candidates for restenosis prevention (procollagen type $1 \mathrm{a} 2$ and ADAM 17/tumour necrosis factor-converting enzyme). ${ }^{8}$ The results of the present study contribute to a better understanding of gene expression in restenosis by a different approach, that is, by demonstrating the correlation between the expression of genes involved in smooth muscle cell structural and functional protein synthesis in atheromatous plaques (de novo lesions) and the amount of intrastent neointima. According to the literature review, this was the first study to report such a correlation.

In clinical practice, the restenosis outcome may vary in the same patient or in the same coronary artery. Therefore, intrastent restenosis appears to be more closely related to intrinsic factors of the atheromatous plaque than to specific variables of the patient or of the coronary artery. Some factors related to the atheromatous plaque, such as plaque load, the presence of lipid content and positive remodelling, have been associated with restenosis. ${ }^{5-7}$ Consistent with these observations, the results of this study support the concept of local predisposition for the development of intrastent restenosis by the increased expression of genes involved in smooth muscle cell structural and functional protein synthesis, which most likely act by exerting a prominent role in the restenosis process.

\section{Study limitations}

Some limitations should be considered in the present study. mRNA extraction and measurement from each atheromatous plaque constitute very important and differential factors in this study; however, the minimum cell number that is necessary for mRNA extraction and analysis is not obtained, as atheromatous plaques contain large amounts of cholesterol esters and a small number of cells. Another limitation is the need for validation of the results by direct measurement of 
protein expression in the atheromatous plaque by a Western blot analysis, which was not performed due to the small number of cells in the samples obtained by guided atherectomy.

The aforementioned are essentially technical limitations of the method (gene expression analysis) and the object of study (fragments of atheromatous plaque). Therefore, these limitations do not compromise the study. The objective of the study was not to definitively clarify the physiopathological mechanisms involved in restenosis but to identify new factors and help further the understanding of the complex process of restenosis, seeking safer and more effective solutions.

\section{CONCLUSIONS}

De novo coronary lesions exhibit an increased expression of genes related to smooth muscle cell structural and functional protein synthesis associated with future significant intrastent neointimal hyperplasia, thus emerging as new therapeutic targets.

\section{CONFLICTS OF INTEREST}

The authors declare no conflicts of interest.

\section{REFERENCES}

1. Costa MA, Simon DI. Molecular basis of restenosis and drugeluting stents. Circulation. 2005;111(17):2257-73.

2. Lemos PA, Hoye A, Goedhart D, Arampatzis CA, Saia F, van der Giessen WJ, et al. Clinical, angiographic, and procedural predictors of angiographic restenosis after sirolimus-eluting stent implantation in complex patients: an evaluation from the Rapamycin-Eluting Stent Evaluated at Rotterdam Cardiology Hospital (RESEARCH) study. Circulation. 2004;109(11):1366-70.

3. Dangas GD, Claessen BE, Caixeta A, Sanidas EA, Mintz GS, Mehran R. In-stent restenosis in the drug-eluting stent era. J Am Coll Cardiol. 2010;56(23):1897-907.

4. Moreno PR, Palacios IF, Leon MN, Rhodes J, Fuster V, Fallon JT. Histopathologic comparison of human coronary in-stent and post-balloon angioplasty restenotic tissue. Am J Cardiol. 1999;84(4):462-6.

5. Hong $\mathrm{YJ}$, Jeong $\mathrm{MH}$, Lim SY, Lee SR, Hong $\mathrm{SN}$, Kim $\mathrm{KH}$, et al. Relation of soft plaque and elevated preprocedural highsensitivity C-reactive protein levels to incidence of in-stent restenosis after successful coronary artery stenting. Am J Cardiol. 2006;98(3):341-5.

6. Ishikawa T, Hatakeyama K, Imamura T, Date H, Shibata Y, Hikichi $Y$, et al. Involvement of C-reactive protein obtained by directional coronary atherectomy in plaque instability and developing restenosis in patients with stable or unstable angina pectoris. Am J Cardiol. 2003;91(3):287-92.

7. Sahara M, Kirigaya H, Oikawa Y, Yajima J, Nagashima K, Hara H, et al. Soft plaque detected on intravascular ultrasound is the strongest predictor of in-stent restenosis: an intravascular ultrasound study. Eur Heart J. 2004;25(22):2026-33.
8. Ashley EA, Ferrara R, King JY, Vailaya A, Kuchinsky A, He X, et al. Network analysis of human in-stent restenosis. Circulation. 2006;114(24):2644-54.

9. Zohlnhofer D, Klein CA, Richter T, Brandl R, Murr A, Nuhrenberg T, et al. Gene expression profiling of human stent-induced neointima by cDNA array analysis of microscopic specimens retrieved by helix cutter atherectomy: Detection of FK506-binding protein 12 upregulation. Circulation. 2001;103(10):1396-402.

10. Welt FG, Rogers C. Inflammation and restenosis in the stent era. Arterioscler Thromb Vasc Biol. 2002;22(11):1769-76.

11. Raudales JC, Zago AJ, Rodrigues PRC, Kosachenco BG, Benetti JC, Dallarosa D, et al. Modelo experimental de reestenose intrastent em artérias coronárias de suínos: efeito do implante de stent sobredimensionado. Rev Bras Cardiol Invasiva. 2010; 18(1):55-61.

12. Zago AC, Raudales JC, Attizzani G, Matte BS, Yamamoto GI, Balvedi JA, et al. Local delivery of sirolimus nanoparticles for the treatment of in-stent restenosis. Catheter Cardiovasc Interv. 2012 May 4. [Epub ahead of print].

13. Lavigne MC, Eppihimer MJ, Cheng R, Barry JJ. Anti-proliferative compouds for the prevention of restenosis. Curr Pharm Des. 2010;16(36):3989-4001.

14. Piekielko-Witkowska A, Nauman A. Alternative splicing and its role in pathologies of the endocrine system. Endokrynol Pol. 2011;62(2):160-70.

15. Cook S, Wenaweser P, Togni M, Billinger M, Morger C, Seiler C, et al. Incomplete stent apposition and very late stent thrombosis after drug-eluting stent implantation. Circulation. 2007;115(18):2426-34

16. Finn AV, Joner M, Nakazawa G, Kolodgie F, Newell J, John MC et al. Pathological correlates of late drug-eluting stent thrombosis: Strut coverage as a marker of endothelialization. Circulation. 2007;115:(18)2435-41.

17. Barlis P, Regar E, Serruys PW, Dimopoulos K, van der Giessen WJ van Geuns RJ, et al. An optical coherence tomography study of a biodegradable vs. durable polymer-coated limus-eluting stent: a LEADERS trial sub-study. Eur Heart J. 2010;31(2):165-76.

18. Guagliumi G, Musumeci G, Sirbu V, Bezerra HG, Suzuki N, Fiocca L, et al. Optical coherence tomography assessment of in vivo vascular response after implantation of overlapping bare-metal and drug-eluting stents. JACC CardiovasC Interv. 2010;3(5):531-9.

19. Zago AC, Matte BS, Reginato L, Iturry-Yamamoto G, Krepsky A, Bergoli LC, et al. First-in-man study of simvastatin-eluting stent in de novo coronary lesions: the SIMVASTENT study. Circ J. 2012;76(5):1109-14.

20. Kereiakes D, Linnemeier TJ, Baim DS, Kuntz R, O'Shaughnessy C, Hermiller J, et al. Usefulness of stent length in predicting instent restenosis (the MULTI-LINK stent trials). Am J Cardiol. 2000;86(3):336-41.

21. Kobayashi Y, De Gregorio J, Kobayashi N, Akiyama T, Reimers B, Finci $\mathrm{L}$, et al. Stented segment length as an independent predictor of restenosis. J Am Coll Cardiol. 1999;34(3):651-9.

22. Mercado N, Boersma E, Wijns W, Gersh BJ, Morillo CA, De Valk V, et al. Clinical and quantitative coronary angiographic predictors of coronary restenosis: a comparative analysis from the balloon-to-stent era. J Am Coll Cardiol. 2001;38(3): 645-52.

23. Rathore S, Terashima M, Katoh O, Matsuo H, Tanaka N, Kinoshita Y, et al. Predictors of angiographic restenosis after drug eluting stents in the coronary arteries: contemporary practice in real world patients. Eurolntervention. 2009;5(3):349-54. 